\title{
Erratum to: Superoxide Dismutase Activity, Hydrogen Peroxide Steady-State Concentration, and Bactericidal and Phagocytic Activities Against Moraxella bovis, in Neutrophils Isolated from Copper-Deficient Bovines
}

\author{
Gabriela Cintia Postma ${ }^{1}$ - Leonardo Minatel ${ }^{1}$ - Roberto Walter Israel Olivares ${ }^{1}$. \\ Andrea Schapira $^{1} \cdot$ Laura Beatriz Valdez $^{2} \cdot$ Maria Elena Dallorso $^{1}$
}

Published online: 2 September 2016

(C) Springer Science+Business Media New York 2016

Erratum to: Biol Trace Elem Res (2016) 171:94-100

DOI 10.1007/s12011-015-0505-2

In the above-mentioned article, the author names Gabriela Cintia Postma, Leonardo Minatel, Roberto Walter Israel Olivares, Andrea Schapira, Laura Beatriz Valdez, Maria Elena Dallorso were written incorrectly; the words in each name were out of sequence. However, these errors have been corrected already in the author listing for this article.

The authors regret the oversight.

The online version of the original article can be found at doi:10.1007 /s12011-015-0505-2

Gabriela Cintia Postma

gabrielapostma@yahoo.com.ar

1 Cátedra de Patología, Facultad de Ciencias Veterinarias, Universidad de Buenos Aires (UBA), Chorroarín 280, C1427CWO Buenos Aires, Argentina

2 Cátedra de Fisicoquímica, Facultad de Farmacia y Bioquímica, Universidad de Buenos Aires, Buenos Aires, Argentina 